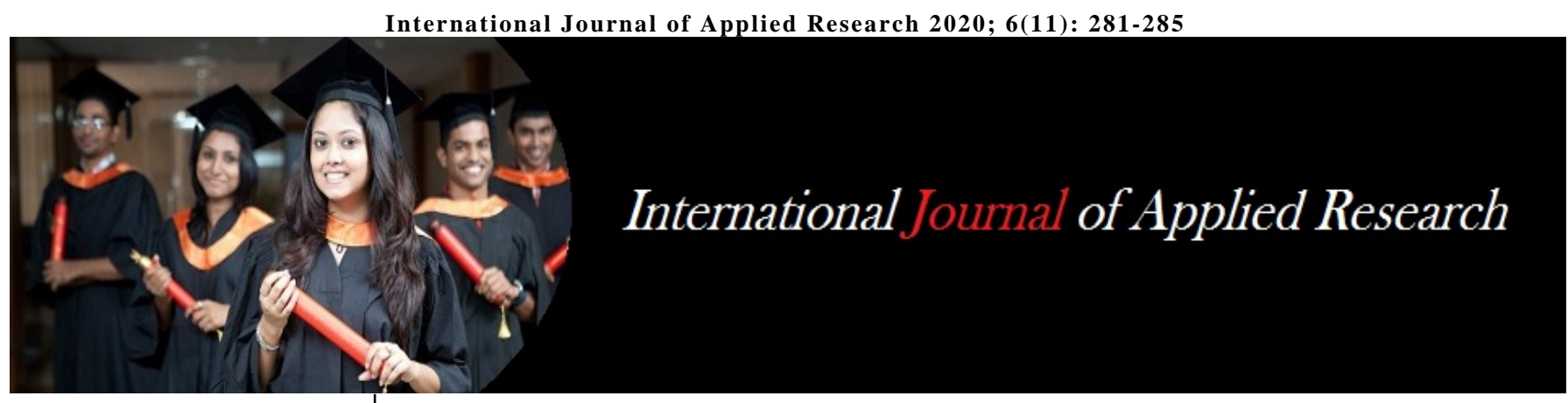

ISSN Print: 2394-7500

ISSN Online: 2394-5869

Impact Factor: 8.4

IJAR 2020; 6(11): 281-285

www.allresearchjournal.com

Received: 17-09-2020

Accepted: 21-10-2020

Salim Shah

Hansraj College, Science

Department, New Delhi, India

Yufeng Wei

Hansraj College, Science

Department, New Delhi, India

Chan Chan

Hansraj College, Science

Department, New Delhi, India
Corresponding Author:

Salim Shah

Hansraj College, Science

Department, New Delhi, India

\section{Effects of particulate matter from air pollution on cardiovascular system of the body}

\author{
Salim Shah, Yufeng Wei and Chan Chan
}

DOI: https://doi.org/10.22271/allresearch.2020.v6.i11e.7813

\section{Abstract}

Air pollution is a mixture of particulate and gaseous components, which will have adverse effects on human health. Depending upon Cause of air pollution, composition varies, and studies from all over the world shown that air pollution has increased mortality. More than gaseous components, particulate matter has greater impact on health, which is proved by serval clinical studies. Particulate components have wide effect on human health especially cardiovascular system of the body. There is increased risk of death from both chronic and acute exposure to PM air pollution. Acute exposure had led to wide range of cardiovascular events like hospital admissions with angina, heart failure, myocardial infraction. Long term exposure led to risk of death from coronary heart disease. Particulate matter from air pollution has been also shown as important factor contributing to obesity and diabetes. An understanding of how PM causes toxic effects on human health is important to prevent and minimize the health effects. Public health problems and mortality rate because of air pollution are expected to double by 2050.In this paper we will review how PM exerts toxic effects on cardiovascular system, and discuss about major studies that established link between particulate matter (PM) air pollution and cardiovascular disease in the humans.

Keywords: Air pollution, gaseous components, increased mortality

\section{Introduction}

Air pollution is a global health problem which causes an estimated death of 3.1 million per year ${ }^{[1,2,3]}$. Majority of the deaths due to air pollution exposure are due to thrombotic (acute ischemic) cardiovascular events. It not only causes mortality, but silently reduces the healthy life span and worker productivity ${ }^{[2,4]}$. Health risk due to exposure of air pollution is the largest environmental health risk, which ranks ninth among other causes. In developed counties air pollution standards are way below target standards ${ }^{[6,7]}$. Air pollution is also an important endocrine disrupter, causing the metabolic diseases like diabetes mellitus ${ }^{[5]}$.

\section{Air Pollution}

Air pollution is a mixture of particulate and gaseous components which has adverse effects on respiratory and cardiovascular systems. The composition of particulate matter depends on the source of air pollution, emission rate wind conditions and sunlight. Nitric oxide (NO), Nitrogen Dioxide (NO2), sulfur dioxide (SO2), ozone (O3), and carbon monoxide (CO) are the main gaseous components which indicate air pollution ${ }^{[2,15,16]}$. Particulate Matter of air pollution contains carbonaceous particles with associated absorbed reactive metals and organic chemicals. Nitrates, Sulphates, endotoxin, polycyclic hydrocarbons, and metals such as Nickel, Zinc, copper ${ }^{[2,9,10]}$. Particulate Matter of air pollution is classified into different categories based on Particle size. First one of category is coarse (PM10, diameter $<10 \mu \mathrm{m})$, second is fine (PM2.5, diameter $<2.5 \mu \mathrm{m}$ ), and third is ultrafine (PM0.1, diameter $<0.1 \mu \mathrm{m})$. Source of coarse particles is from natural and industrial sources and usually do not penetrate beyond upper bronchus. Sources of fine and ultra-fine particles are combustion of fossil fuels, and these particles are of greater threat to health and can penetrate smaller airways ${ }^{[11,12]}$. 


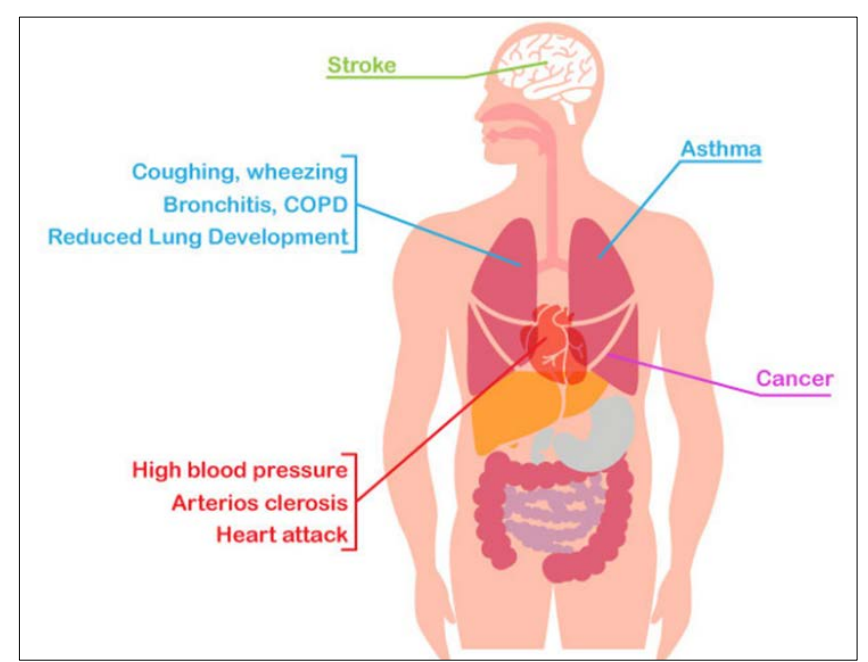

Fig 1: Different affects of air pollution on Human body

\section{Cardiovascular effects \\ Myocardial ischaemia}

During the submaximal exercise tolerance testing in elder patients who has heart coronary heart disease, it was noticed that exposure to PM of air pollution has increased the risk of ST-segment depression ${ }^{[13,14,15]}$. This risk was higher when the exposed to combustion derived particulate matter ${ }^{[15]}$. Similarly a test was conducted and recordings were taken while doing exercise outdoors, before and after the exercise, and exposure to black carbon derived from traffic has increased ST-segment depression in elder heart patients ${ }^{[16]}$. ST-segments depression has increased in elderly patients with coronary heart disease during 24 hour electrocardiographic recordings due to the exposure of black carbon and PM2.5 exposure ${ }^{[17]}$. The same thing is observed in patients of acute coronary syndromes ${ }^{[18]}$. A study was conducted on patients in Beijing using face mask and walking around in the center of Beijing and it was noticed that ST-segment depression was reduced ${ }^{[19]}$. Recent studies on association of new Coronavirus COVID-19 has increased threat to heart myocardial injury ${ }^{[20]}$.

\section{Vasoconstriction and arterial stiffness}

In a study by ${ }^{[21]}$ which is done by controlled exposure of concentrated ambient particles from air pollution in order to assess vascular function, demonstrated the occurrence of vasoconstriction of the brachial artery. Similar study was made on healthy people and people with metabolic syndrome and acute vasoconstriction was observed after being exposed to diesel exhaust ${ }^{[22]}$. In another cardiovascular study, based on exposure to air pollution which was measure using portable monitoring equipment, and it was found that exposure to particulate matter, increased the vasoconstriction ${ }^{[23]}$. It was demonstrated that there is an immediate increase in central arterial stiffness after being exposed to dilute diesel exhaust with also an increase in arterial tone and vasoconstriction ${ }^{[24]}$. In a study which is done on children, central arterial stiffness is found to higher in children living close to major roads, than children living far away from heavily pouted areas due to traffic ${ }^{[25]}$.

\section{Oxidative stress, Inflammation}

PM inhalation induces inflammatory responses within lungs. In a study which was done on some volunteers, they are exposed to PM via inhaling process for about two hours, has increased pulmonary neutrophil numbers [26]. Systemic inflammatory can mediate the exposure to air pollution to local responses which in turn is driven by oxidative stress. Some studies showed the association between PM air pollution and acute phase response by increase in plasma viscosity ${ }^{[27]}$, C-reactive protein ${ }^{[28]}$ and fibrinogen ${ }^{[29]}$.

Biological effects via Oxidative stress or generation of reactive oxygen species (ROS) is associated with $\mathrm{PM}^{[30,31]}$. Systemic makers of oxidative stress is associated with air pollution exposure [32, 33, 34]. Many cell types respond with elevations in cellular ROS levels and oxidative stress due to PM exposure. This includes lung epithelial cells, nasal, airway, macrophages, gastrointestinal epithelial cells, cardiomyocytes and corneal epithelial cells [35-41]. PM exposure also is associated with systemic makers of oxidative stress, including atherogenic precursors, oxidized lipids ${ }^{[42-45]}$.

\section{Cardiac arrhythmias and Cardiac rate variability}

Incidence of cardiac arrhythmias including ventricular tachycardia and atrial fibrillation, and ventricular fibrillation are associated with Short term exposure to air pollution ${ }^{[45]}$. Heart rate increase is associated with exposure to air pollution along with electric instability, ectopic beats, repolarization irregularities and changes in heart rate variability ${ }^{[56]}$.

In a study ${ }^{[45]}$ done on people with arrhythmia, a strong correlation between occurrence of arrhythmia and pollution exposure has been found and it concludes that risk of arrhythmias is more in people who already have it. Another study done on wild type of mice suggested that no occurrence of arrhythmia is found in mice after exposure to $\mathrm{PM}$, but arrhythmias is seen in mice engineered to exhibit cardiomyopathic changes that resemble to heart failure ${ }^{[47]}$. Epidemiological studies demonstrated that short term exposure to PM air pollution has increased hospital admissions with heart failure, and arrhythmias. Exposure to PM has associated incidence of ventricular arrhythmias in patients with automated implantable defibrillators. Sudden cardiac death is associated with ventricular arrhythmias with the activity of the autonomic nervous system. In susceptible patients there is likelihood of developing ventricular arrhythmias due to reduced heart the variability ${ }^{[48]}$.

Following a 2-hour exposure to PM in healthy elderly people, heart rate variability has reduced, and remained weakened up to 24 hour after the exposure ${ }^{[49]}$. ${ }^{[50]}$ Healthy volunteers are exposed to PM of different size fractions and changes in heart rate variability are assessed and it was found that there is no relationship between heart rate variability and exposure to different sizes of PM particles. But it was found that there is a reduction in indices of heart rate variability by exposure to coarse particles between 2.5 and $10 \mu \mathrm{m}$ in diameter. Due to the recent pandemic and quarantine caused by Coronavirus there is a significant reduction in levels of $\mathrm{NO}_{2}$, and air pollution has reduced due to less traffic ${ }^{[46]}$.

\section{Blood pressure}

Association of hypertension and air pollution has been studied extensively and has been the subject of these different studies ${ }^{[51,52,53,54]}$. An elevation in systolic acid and diastolic blood pressure with 1 to $3 \mathrm{~mm} \mathrm{Hg}$ are associated with an increase in ambient PM2.5 by $10 \mu \mathrm{g} / \mathrm{m} 3$. There is an increase in blood pressure noticed in people who are 
exposed to long term air pollution with an incidence of hypertension In many studies as well. In studies which are controlled, performed on humans, association of air pollution with a variety of vascular alterations resulted in changes of blood pressure ${ }^{[55]}$. Some strategies used to lower air pollution demonstrated fact effects in reducing blood pressure, by confirming the direct impact of inhalation of air on blood pressure. This evidence supports the impact of air pollution on inclusion of higher blood pressure and hypertension. In a study sugarcane harvester found that, during the harvest time, at the time of burning sugarcane the $\mathrm{PM}$ is high and due to inhaling it workers blood pressure and heart rate variability measurements correlated with sympathetic nerve activity.

\section{Conclusion}

It is very evident that air pollution is a major cause to cardiovascular mortality and morbidity. Exposing ourselves to pollution is a major modifiable risk in managing the prevention of cardiovascular disease, and effects of air pollution are not just limited to cardiovascular system of body.PM is also a contributor to development of metabolic diseases like obesity and diabetes is also studied that puberty in men and women can also be effected by air pollution. Air pollution also affects central nervous system, and gastrointestinal tract. There is no safe level of PM exposure, so in addition to putting efforts to reduce air pollution and exposure, studies should focus on mechanisms to better understand how PM can cause adverse health effects. There should be awareness that should be brought in the public, education on the harmful effects of air pollution especially on patients with underlying health issues. And finally, we all should contribute in our daily levels to lessen the air pollution.

\section{References}

1. Lelieveld J, Evans JS, Fnais M, Giannadaki D, Pozzer A. The contribution of outdoor air pollution sources to premature mortality on a global scale. Nature 2015;525:367-71. doi: 10.1038/nature15371 PubMed Abstract | CrossRef Full Text | Google Scholar

2. Newby DE, Mannucci PM, Tell GS, Baccarelli AA, Brook RD, Donaldson K et al. Expert position paper on air pollution and cardiovascular disease. Eur Heart J 2015;36:83-93b. doi: 10.1093/eurheartj/ehu458 PubMed Abstract | CrossRef Full Text | Google Scholar

3. Brook RD, Newby DE, Rajagopalan S. The global threat of outdoor ambient air pollution to cardiovascular health: time for intervention. JAMA Cardiol 2017;2:353-4. doi: 10.1001/jamacardio.2017.0032 PubMed Abstract | CrossRef Full Text | Google Scholar

4. Zivin JG, Neidell M. Air pollution's hidden impacts. Science 2018;359:39-40. doi: 10.1126/science.aap7711 PubMed Abstract | CrossRef Full Text | Google Scholar

5. Darbre PD. Overview of air pollution and endocrine disorders. Int J Gen Med 2018;11:191-207. doi: 10.2147/IJGM.S102230 PubMed Abstract|CrossRef Full Text | Google Scholar

6. Mills NL, Donaldson K, Hadoke PW, Boon NA, MacNee W, Cassee FR et al. Adverse cardiovascular effects of air pollution. Nat Clin Pract Cardiovasc Med 2009;6:36-44. doi: 10.1038/ncpcardio1399 PubMed Abstract | CrossRef Full Text | Google Scholar
7. Cosselman KE, Navas-Acien A, Kaufman JD. Environmental factors in cardiovascular disease. Nat Rev Cardiol 2015;12:627-42. doi: 10.1038/nrcardio.2015.152

8. Brook RD, Rajagopalan S, Pope CA III, Brook JR, Bhatnagar A, Diez-Roux AV et al. Particulate matter air pollution and cardiovascular disease: an update to the scientific statement from the American Heart Association. Circulation 2010;121:2331-78. doi: 10.1161/CIR.0b013e3181dbece1 PubMed Abstract | CrossRef Full Text | Google Scholar

9. Chin MT. Basic mechanisms for adverse cardiovascular events associated with air pollution. Heart 2015;101:253-6. doi: 10.1136/heartjnl-2014-306379 PubMed Abstract | CrossRef Full Text | Google Scholar

10. Brook RD, Franklin B, Cascio W, Hong Y, Howard G, Lipsett $\mathrm{M}$ et al. Air pollution and cardiovascular disease: a statement for healthcare professionals from the Expert panel on population and prevention science of the american heart association. Circulation 2004;109:2655-71. doi: 10.1161/01.CIR.0000128587.30041.C8 PubMed Abstract | CrossRef Full Text | Google Scholar

11. Pope CA III. Epidemiology of fine particulate air pollution and human health: biologic mechanisms and who's at risk? Environ Health Perspect 2000;108(Suppl. 4):713-23. doi: 10.1289/ehp.108-1637679 PubMed Abstract | CrossRef Full Text | Google Scholar

12. Miller MR, Shaw CA, Langrish JP. From particles to patients: oxidative stress and the cardiovascular effects of air pollution. Future Cardiol 2012;8:577-602. doi: 10.2217/fca.12.43 PubMed Abstract|CrossRef Full Text | Google Scholar

13. Lanki T, Hoek G, Timonen KL et al. Hourly variation in fine particle exposure is associated with transiently increased risk of ST segment depression. Occup Environ Med 2008;65:782-6. Crossref CAS PubMed Web of Science ${ }^{\circledR G}$ Google Scholar

14. Pekkanen J, Peters A, Hoek G et al. Particulate air pollution and risk of ST-segment depression during repeated submaximal exercise tests among subjects with coronary heart disease: the exposure and risk assessment for fine and ultrafine particles in ambient air (ULTRA) study. Circulation 2002;106:933-8. Crossref PubMed Web of Science ${ }^{\circledR}$ Google Scholar

15. Lanki T, Hartog JD, Heinrich J et al. Can we identify sources of fine particles responsible for exercise-induced ischemia on days with elevated air pollution? The ULTRA study. Environ Health Perspect 2006;114:655-60. Crossref CAS PubMed Web of Science ${ }^{\circledR G}$ Google Scholar

16. Gold D, Litonjua A, Zanobetti A et al. Air pollution and ST-segment depression in elderly subjects. Environ Health Perspect 2005;113:883-7. Crossref CAS PubMed Web of Science ${ }^{\circledR}$ Google Scholar

17. Delfino RJ, Gillen DL, Tjoa $\mathrm{T}$ et al. Electrocardiographic ST-segment depression and exposure to traffic-related aerosols in elderly subjects with coronary artery disease. Environ Health Perspect 2011;119:196-202.

18. Chuang KJ, Coull BA, Zanobetti A et al. Particulate air pollution as a risk factor for ST-segment depression in patients with coronary artery disease. Circulation 2008;118:1314-20. 
19. Langrish JP, Li X, Wang S et al. Reducing personal exposure to particulate air pollution improves cardiovascular health in patients with coronary heart disease. Environ Health Perspect 2011;120:367-72.

20. Ravi Manne, Snigdha Kantheti. Coronavirus Impact on Cardiovascular System of Body - Review. International Journal for Research in Applied Science and Engineering Technology (IJRASET) 2020;8(11):276280, CrossRef https://doi.org/10.22214/ijraset.2020.32118

21. Brook R, Brook J, Urch B, Vincent R, Rajagopalan S, Silverman F. Inhalation of fine particulate air pollution and ozone causes acute arterial vasoconstriction in healthy adults. Circulation 2002;105:1534-6. Crossref CAS PubMed Web of Science ${ }^{\circledR}$ Google Scholar

22. Peretz A, Sullivan JH, Leotta DF et al. Diesel exhaust inhalation elicits acute vasoconstriction in vivo. Environ Health Perspect 2008;116:937-42. Crossref CAS PubMed Web of Science ${ }^{\circledR}$ Google Scholar

23. Brook RD, Bard RL, Burnett RT et al. Differences in blood pressure and vascular responses associated with ambient fine particulate matter exposures measured at the personal versus community level. Occup Environ Med 2011;68:224-30. Crossref PubMed Web of Science ${ }^{\circledR}$ Google Scholar

24. Lundback M, Mills NL, Lucking A et al. Experimental exposure to diesel exhaust increases arterial stiffness in man. Part Fibre Toxicol 2009;6:7.

25. Iannuzzi A, Verga MC, Renis M et al. Air pollution and carotid arterial stiffness in children. Cardiol Young 2010;20:186-90.

26. Ghio AJ, Kim C, Devlin RB. Concentrated ambient air particles induce mild pulmonary inflammation in healthy human volunteers. Am J Respir Crit Care Med 2000;162:981-8. doi: 10.1164/ajrccm.162.3.9911115

27. Peters A, Döring A, Wichmann H, Koenig W. Increased plasma viscosity during an air pollution episode: a link to mortality? Lancet 1997;349:1582-7.

28. Peters A, Fröhlich M, Döring A et al. Particulate air pollution is associated with an acute phase response in men. Results from the Monica-Augsburg study. Eur Heart J 2001;22:1198-204.

29. Pekkanen J, Brunner E, Anderson H, Tiitanen P, Atkinson R. Daily concentrations of air pollution and plasma fibrinogen in London. Occup Environ Med 2000;57:818-22.

30. Miller MR, Shaw CA, Langrish JP. From particles to patients: oxidative stress and the cardiovascular effects of air pollution. Future Cardiol 2012;8:577-602. doi: 10.2217/fca.12.43

31. Rao X, Zhong J, Brook RD, Rajagopalan S. Effect of particulate matter air pollution on cardiovascular oxidative stress pathways. Antioxid Redox Signal 2018;28:797-818. doi: 10.1089/ars.2017.7394

32. Moller P, Loft S. Oxidative damage to DNA and lipids as biomarkers of exposure to air pollution. Environ Health Perspect 2010;118:1126-36. doi: 10.1289/ehp.0901725

33. Huang W, Wang G, Lu SE, Kipen H, Wang Y, Hu M et al. Inflammatory and oxidative stress responses of healthy young adults to changes in air quality during the Beijing Olympics. Am J Respir Crit Care Med 2012;186:1150-9. doi: 10.1164/rccm.201205-0850OC
34. Yin F, Lawal A, Ricks J, Fox JR, Larson T, Navab M et al. Diesel exhaust induces systemic lipid peroxidation and development of dysfunctional pro-oxidant and proinflammatory high-density lipoprotein. Arterioscler Thromb Vasc Biol 2013;33:1153-61. doi: 10.1161/ATVBAHA.112.300552

35. Mutlu GM, Snyder C, Bellmeyer A, Wang H, Hawkins $\mathrm{K}$, Soberanes $\mathrm{S}$ et al. Airborne particulate matter inhibits alveolar fluid reabsorption in mice via oxidant generation. Am J Respir Cell Mol Biol 2006;34:670-6. doi: $\quad$ 10.1165/rcmb.2005-03290C PubMed Abstract | CrossRef Full Text | Google Scholar

36. Soberanes S, Panduri V, Mutlu GM, Ghio A, Bundinger GR, Kamp DW. p53 mediates particulate matterinduced alveolar epithelial cell mitochondria-regulated apoptosis. Am J Respir Crit Care Med 2006;174:122938. doi: 10.1164/rccm.200602-203OC PubMed Abstract | CrossRef Full Text | Google Scholar

37. Manzo ND, LaGier AJ, Slade R, Ledbetter AD, Richards JH, Dye JA. Nitric oxide and superoxide mediate diesel particle effects in cytokine-treated mice and murine lung epithelial cells-implications for susceptibility to traffic-related air pollution. Part Fibre Toxicol 2012;9:43. doi: 10.1186/1743-8977-9-43

38. Wang J, Huang J, Wang L, Chen C, Yang D, Jin M et al. Urban particulate matter triggers lung inflammation via the ROS-MAPK-NF-kappa B signaling pathway. J Thorac Dis 2017;9:4398-412. doi: 10.21037/jtd.2017.09.135

39. PubMed Abstract | CrossRef Full Text | Google Scholar

40. Hong Z, Guo Z, Zhang R, Xu J, Dong W, Zhuang G et al. Airborne fine particulate matter induces oxidative stress and inflammation in human nasal epithelial cells. Tohoku J Exp Med 2016;239:117-25. doi: 10.1620/tjem.239.117

41. Moller P, Loft S. Oxidative damage to DNA and lipids as biomarkers of exposure to air pollution. Environ Health Perspect 2010;118:1126-36. doi: 10.1289/ehp.0901725 PubMed Abstract | CrossRef Full Text | Google Scholar

42. Jacobs L, Emmerechts J, Hoylaerts MF, Mathieu C, Hoet PH, Nemery B et al. Traffic air pollution and oxidized LDL. PLoS One 2011;6:e16200. doi: 10.1371/journal.pone.0016200 PubMed Abstract | CrossRef Full Text | Google Scholar

43. Huang W, Wang G, Lu SE, Kipen H, Wang Y, Hu M et al. Inflammatory and oxidative stress responses of healthy young adults to changes in air quality during the Beijing Olympics. Am J Respir Crit Care Med 2012;186:1150-9. doi: 10.1164/rccm.201205-0850OC PubMed Abstract | CrossRef Full Text | Google Scholar

44. Yin F, Lawal A, Ricks J, Fox JR, Larson T, Navab M et al. Diesel exhaust induces systemic lipid peroxidation and development of dysfunctional pro-oxidant and proinflammatory high-density lipoprotein. Arterioscler Thromb Vasc Biol 2013;33:1153-61. doi: 10.1161/ATVBAHA.112.300552

45. Dockery DW, Luttmann-Gibson H, Rich DQ, Link MS, Mittleman MA, Gold DR et al. Association of air pollution with increased incidence of ventricular tachyarrhythmias recorded by implanted cardioverter defibrillators. Environ Health Perspect 2005;113:670-4. doi: 10.1289/ehp.7767 
46. Ravi Manne, Snigdha Kantheti. COVID-19 and Its Impact on Air Pollution. International Journal for Research in Applied Science and Engineering Technology (IJRASET) 2020;8(11):344-346 CrossRef. https://doi.org/10.22214/ijraset.2020.32139

47. Wang T, Lang GD, Moreno-Vinasco L, Huang Y, Goonewardena SN, Peng YJ et al. Particulate matter induces cardiac arrhythmias via dysregulation of carotid body sensitivity and cardiac sodium channels. Am J Respir Cell Mol Biol 2012;46:524-31. doi: 10.1165/rcmb.2011-0213OC

48. Reed MJ, Robertson CE, Addison PS. Heart rate variability measurements and the prediction of ventricular arrhythmias. QJM 2005;98:87-95.

49. Devlin RB, Ghio AJ, Kehrl H, Sanders G, Cascio W. Elderly humans exposed to concentrated air pollution particles have decreased heart rate variability. Eur Respir J Suppl 2003;40:76s-80s.

50. Samet JM, Graff D, Berntsen J, Ghio AJ, Huang YC, Devlin RB. A comparison of studies on the effects of controlled exposure to fine, coarse and ultrafine ambient particulate matter from a single location. Inhal Toxicol 2007;19(Suppl 1):29-32

51. Liang R, Zhang B, Zhao X, Ruan Y, Lian H, Fan Z. Effect of exposure to PM2.5 on blood pressure: a systematic review and meta-analysis. J Hypertens 2014;32:2130. Discussion 2141.

52. Giorgini P, Di Giosia P, Grassi D, Rubenfire M, Brook RD, Ferri C. Air pollution exposure and blood pressure: an updated review of the literature. Curr Pharm Des 2016;22:28.

53. Cai Y, Zhang B, Ke W et al. Associations of short-term and long-term exposure to ambient air pollutants with hypertension: a systematic review and meta-analysis. Hypertension 2016;68:62.

54. Yang BY, Qian Z, Howard SW et al. Global association between ambient air pollution and blood pressure: a systematic review and meta-analysis. Environ Pollut 2018;235:576.

55. Münzel T, Sørensen M, Gori T et al. Environmental stressors and cardio-metabolic disease: part IImechanistic insights. Eur Heart J 2017;38:557.

56. Riediker M, Cascio WE, Griggs TR, Herbst MC, Bromberg PA, Neas L et al. Particulate matter exposure in cars is associated with cardiovascular effects in healthy young men. Am J Respir Crit Care Med 2004;169:934-40. doi: 10.1164/rccm.200310-1463OC 